\title{
Apes and Tricksters: The Evolution and Diversification of Humans' Closest Relatives
}

\author{
Kieran P. McNulty
}

Published online: 3 August 2010

(C) Springer Science+Business Media, LLC 2010

\begin{abstract}
The evolutionary history of humans comprises an important but small branch on the larger tree of ape evolution. Today's hominoids - gibbons, orangutans, gorillas, chimpanzees, and humans - are a meager representation of the ape diversity that characterized the Old World from 23-5 million years ago. In this paper, I briefly review this evolutionary history focusing on features important for understanding modern ape and human origins. As the full complexity of ape evolution is beyond this review, I characterize major geographic, temporal, and phylogenetic groups using a few flagship taxa. Improving our knowledge of hominoid evolution both complicates and clarifies studies of human origins. On one hand, features thought to be unique to the human lineage find parallels in some fossil ape species, reducing their usefulness for identifying fossil humans. On the other hand, the Miocene record of fossil apes provides an important source for generating hypotheses about the ancestral human condition; this is particularly true given the dearth of fossils representing our closest living relatives: chimpanzees and gorillas.
\end{abstract}

Keywords Hominoid evolution · Apes · Miocene ·

Human origins

\section{Introduction}

Well before there was an evolutionary framework to unite all living organisms, Carl Linnaeus (von Linnaeus 1759) recognized the place of humans alongside the apes in his

\section{K. P. McNulty ( $\bowtie)$}

Evolutionary Anthropology Laboratory,

Department of Anthropology, University of Minnesota,

Minneapolis, MN 55455, USA

e-mail: kmcnulty@umn.edu eighteenth century Systema Naturae. Darwin also identified our similarities to the African gorillas and chimpanzees, and today our place within the Hominoidea (the taxonomic group encompassing apes and humans) is now well established. We share a number of derived features with living apes that distinguish us from other primates: tail loss, upright posture, shortened trunks, enhanced grasping capabilities, large brains relative to body size, flexible forelimbs, slow maturation, and a long life span. The advent of modern genetic analyses (Caccone and Powell 1989; Goodman et al. 1990; Ruvolo 1997; Ruvolo et al. 1994) fully resolved our rightful place among the living apes (Fig. 1). And while our close tie to chimpanzees initially raised a few eyebrows, it is now clear that we humans share a number of characteristics with our recentlydivided sister lineage.

From this perspective, the origin of the human lineage can only be properly understood within the context of the larger tree of hominoid diversity from which our small but vigorous branch emerged. Today, there are only five types of hominoid left on this tree, and with the exception of gibbons, none of these is very speciose. This heavily pruned bole represented in Fig. 1 stands in dramatic contrast to the vibrant, multifurcating tree of fossil apes that lived in the Miocene epoch, 23.05.3 million years ago (Ma). Even conservative practitioners ("lumpers," in common parlance) might name dozens of ape genera from the fossils that have been discovered thus far; "splitters" might recognize more than 50. Considering the potential for multiple species within each of these groups, it seems that one could hardly take a step through the Miocene geography without tripping over another type of ape.

Table 1 provides a list of hominoids and other closely related primates that figure in the origin, evolution, and 
Fig. 1 Evolutionary relationships among living apes and humans. The timeline charts major splitting events (large bullets) between ape lineages, which are taken from Raaum et al. (2005) and references therein. Fossil apes featured in the text are also plotted with lines approximating their temporal ranges in the fossil record (Begun 2007; Benefit and McCrossin 1995; Heizmann and Begun 2001; MacLatchy et al. 2006; Peppe et al. 2009). Shaded regions correspond to the phylogeographic groups discussed in the text, and their placement across major splitting events represents both current debates over the relationships of their constituent taxa as well as, in some cases, the likelihood that these convenient geotemporal groups comprise members of multiple evolutionary lineages. Shaded regions are not calibrated to the timescale

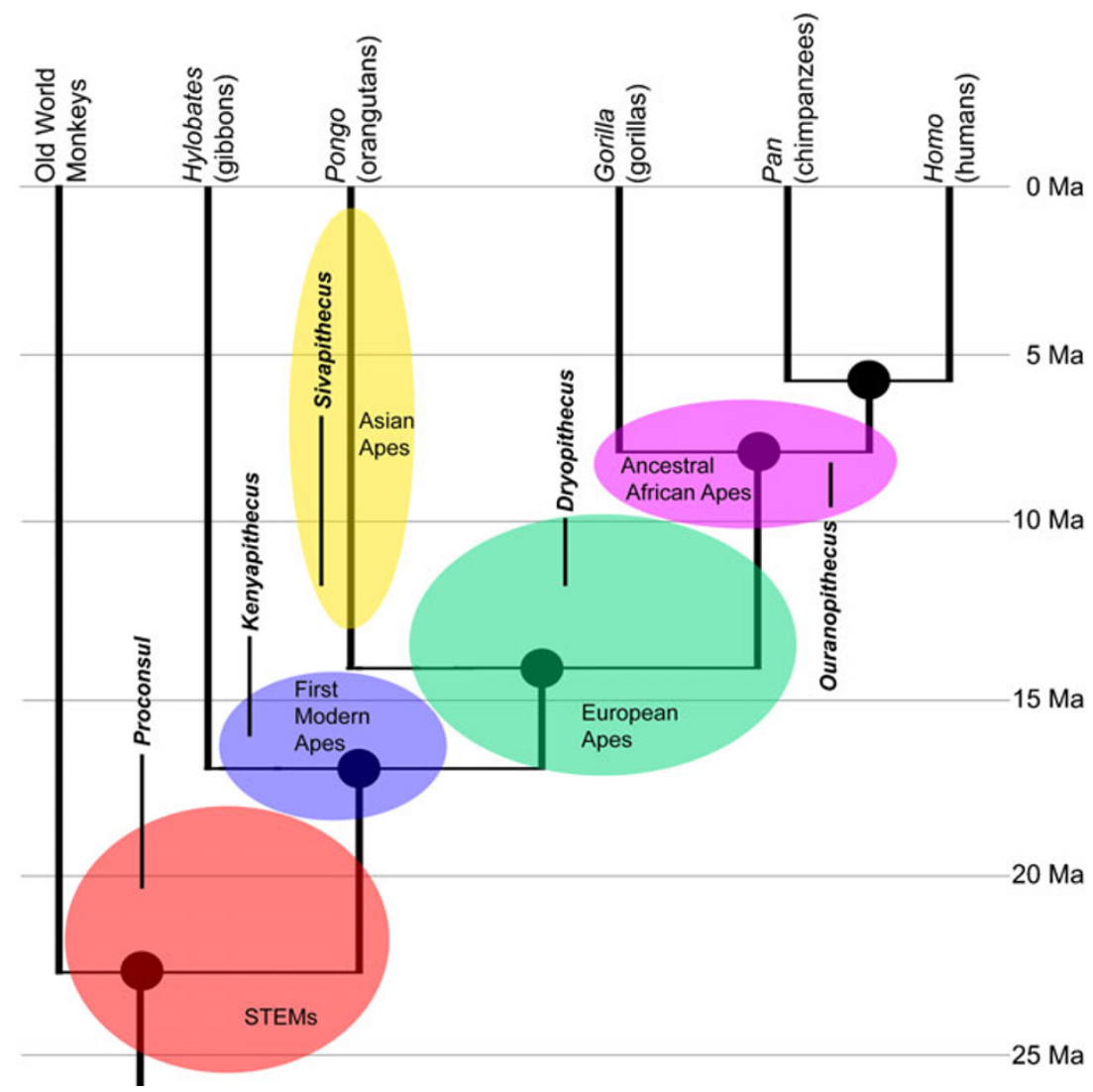

diversification of the ape and human lineage. Many of these names end in "pithecus," which derives from the Greek word ( $\pi i \theta \eta \kappa o \varsigma)$ meaning ape or trickster (Oxford English Dictionary, 2nd Edition, 1989). While the scientists who thought up the names undoubtedly meant to reference the former meaning, this double entendre is entirely appropriate given the numerous unresolved debates surrounding the evolution of Miocene apes. Sorting out these trickstersdetermining how they relate to each other and to modern apes, how different features of modern apes evolved over
Table 1 Convenient phylogeographic groups of hominoids

${ }^{\text {a }}$ Taxa featured in the text

\begin{tabular}{|c|c|c|c|c|c|}
\hline $\begin{array}{l}\text { Modern } \\
\text { hominoids }\end{array}$ & STEMs & $\begin{array}{l}\text { First modern } \\
\text { apes }\end{array}$ & European apes & Asian apes & $\begin{array}{l}\text { Ancestral African } \\
\text { apes }\end{array}$ \\
\hline $\begin{array}{l}\text { Hylobates } \\
\text { Pongo } \\
\text { Gorilla } \\
\text { Pan } \\
\text { Homo }\end{array}$ & $\begin{array}{l}\text { Kamoyapithecus } \\
\text { Dendropithecus } \\
\text { Micropithecus } \\
\text { Simiolus } \\
\text { Proconsul }^{\text {a }} \\
\text { Heliopithecus } \\
\text { Afropithecus } \\
\text { Morotopithecus } \\
\text { Nyanzapithecus } \\
\text { Mabokopithecus } \\
\text { Limnopithecus } \\
\text { Turkanapithecus } \\
\text { Ranwapithecus } \\
\text { Kalepithecus } \\
\text { ?Samburupithecus }\end{array}$ & $\begin{array}{l}\text { Griphopithecus } \\
\text { Kenyapithecus }^{\mathrm{a}} \\
\text { Nacholapithecus } \\
\text { Otavipithecus } \\
\text { Equatorius }\end{array}$ & $\begin{array}{l}\text { Dryopithecus }^{\mathrm{a}} \\
\text { Oreopithecus } \\
\text { Pierolapithecus } \\
\text { Anoiapithecus }\end{array}$ & $\begin{array}{l}\text { Sivapithecus }^{\mathrm{a}} \\
\text { Gigantopithecus } \\
\text { Ankarapithecus } \\
\text { Lufengpithecus } \\
\text { Khoratpithecus } \\
\text { Yuanmoupihecus }\end{array}$ & $\begin{array}{l}\text { Ouranopithecus }^{\mathrm{a}} \\
\text { Nakalipithecus } \\
\text { Chororapithecus } \\
\text { Graecopithecus }\end{array}$ \\
\hline
\end{tabular}


time, how their habitats impacted their evolution-is a crucial but often overlooked step in understanding the origin of our human lineage. Indeed, recent discoveries of early fossil humans (Brunet et al. 2002; Senut et al. 2001; White et al. 2009) have underscored the importance of Miocene hominoid diversity in trying to reconstruct the nature of the last ancestor shared by chimpanzees and humans.

In this paper, I review briefly the origin and evolution of hominoids, focusing primarily on the rich fossil record from the Miocene epoch. Since a detailed discussion of every Miocene ape is beyond the scope of this review, I have instead adopted a phylogeographic approach that samples better-known and key fossil groups from the geographic distribution of hominoid lineages.

\section{Stem Taxa from the Early Miocene (STEMs)}

The oldest ape-like fossils are found in Africa from a time when it was still an island continent. As early as 25 million years ago (Boschetto et al. 1992), ape-like primates were living in East Africa, and this diverse and successful community thrived for more than ten million years (Kunimatsu et al. 2007; Pickford and Kunimatsu 2005). Many researchers regard at least some of these primates as true hominoids - belonging to the ape and human lineagewhile relegating others to more primitive groups. But regardless of whether some are classified as "stem catarrhines" (related to but not specifically belonging with either Old World monkeys or apes) and others may be "stem hominoids" (related to but not uniquely linked to modern ape lineages), the importance of these primates for understanding the origin of the ape-human lineage (Andrews and Harrison 2005) makes it appropriate to discuss them simply as STEMs: stem taxa from the Early Miocene.

The best known of these STEMs is the genus Proconsul (Fig. 2), known primarily from sites in Uganda and Kenya dated between 20 and 17 Ma (Bishop et al. 1969; MacLatchy et al. 2006; Peppe et al. 2009). Kenyan sites on Rusinga and Mfangano Islands have provided much of the material attributed to Proconsul, and discoveries there of more than a dozen partial skeletons and hundreds of isolated fossils have documented nearly every aspect of its skeletal anatomy. These fossils demonstrate that Proconsul's basic body plan was similar to primates who scurry on top of tree branches rather than to the below branch, suspensory-adapted extant apes (Rose 1983; Rose 1993; Rose 1994). Combined with a growing realization that many of Proconsul's craniodental similarities to apes are evolutionary holdovers from a more primitive ancestry (Harrison 1987), this evidence led some researchers (e.g., Harrison 1987, 1988, 1993, 2002) to place Proconsul and most of these Early Miocene primates outside of the ape and human lineage.

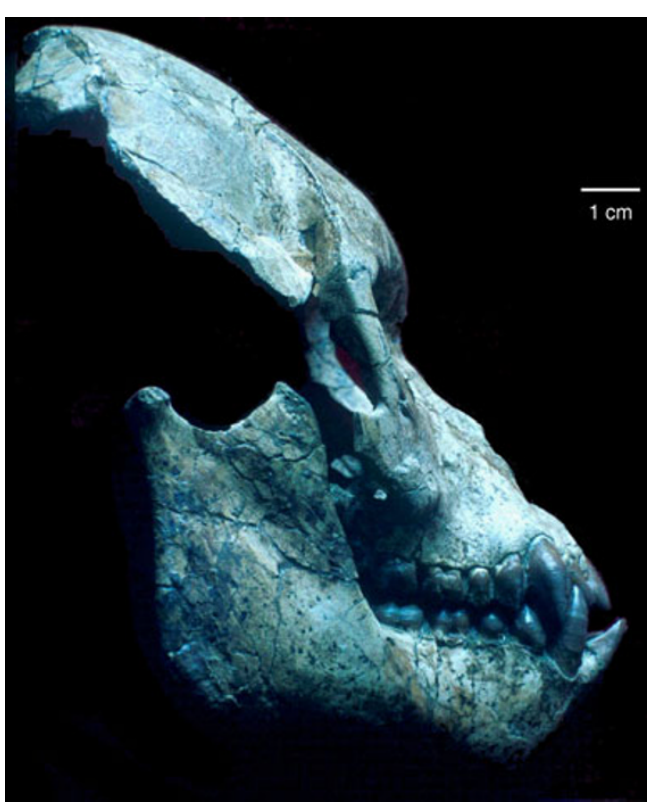

Fig. 2 Fossil skull of Proconsul heseloni (KNM-RU 7290) from Rusnga Island, Kenya. This specimen was found in 1948 during an expedition led by Louis and Mary Leakey and provided some of the first evidence of the cranial features present in the earliest fossil apes. Years of subsequent fieldwork have recovered many partial skeletons of Proconsul so that now, nearly the entire skeleton is represented in collections. Photo courtesy of Eric Delson

Despite its many primitive skeletal features, Proconsul does display some features that may warrant its inclusion among apes. The most obvious ape-like feature of Proconsul is the lack of an external tail (Nakatsukasaa et al. 2004; Ward et al. 1991). It also shares enhanced grasping capabilities (Begun 1994) and a stabilized elbow joint (Rose 1988, 1992) with all of the extant apes, and has a few facial features reminiscent of the living great apes (Rae 1997, 1999, 2004). Interestingly, the largest but also oldest species of Proconsul (Proconsul major, also called "Ugandapithecus" by some workers) is more similar to modern apes than the smaller, younger species (Harrison 2002). Additional evidence suggests that Proconsul's growth and development was slower than that of Old and New World monkeys, more like the life history of the apes (Kelley 1997). In all, the number of features shared by Proconsul and the surviving modern apes are relatively few, but even a small number of shared derived features is regarded as significant evidence compared to an otherwise very primitive skeleton (see Harrison 2002 for a different interpretation). For this reason, most researchers place this STEM taxon among the earliest fossil apes.

While not as well known as Proconsul, other STEMs display intriguing similarities to the modern apes. Morotopithecus is one of the oldest members of this group, living in Uganda more than $20 \mathrm{Ma}$ and combining a primitive face with more modern back and shoulder, 
indicative of suspensory behaviors (MacLatchy 2004). In a contrasting example, the smaller primate Rangwapithecus is nearly as old (Pickford and Andrews 1981) and has a modern ape-like lower face (McNulty 2003; see also Ward et al. 1983; McCrossin and Benefit 1994) but a primitive Proconsul-like skeleton (Rose 1997; Ward 1997a). This sort of evolutionary mosaicism-where more advanced features first appear in multiple species rather than aggregating in a single lineage over time-is becoming commonplace as we learn more about primate evolution, and serves to caution researchers against creating simple, linear models of adaptation and evolution.

\section{The First Modern Apes}

By the late Early Miocene, Africa was no longer isolated from the rest of the Old World, and terrestrial connections to Eurasia provided long periods of faunal interchange between the land masses (Rögl 1998). Apes first appeared in Eurasia around this time at fossil sites in Germany and Turkey just younger than 17 Ma (Heizmann and Begun 2001). By $15 \mathrm{Ma}$, a more advanced grade of ape also inhabited East African sites, overlapping with a few long-surviving lineages of STEM primates. The exact relationships between earlier East African STEMs and these more advanced apes are still debated, but most researchers agree that the new Middle Miocene species belong in the ape and human lineage (Begun 2007; Begun et al. 1997; Benefit and McCrossin 1995; Harrison 1992, 2010; Ward and Duren 2002).

Paleoanthropologists have long been criticized for liberally assigning new names to every new fossil discovery. This is demonstrably not the case with the Middle Miocene apes from Kenya, which researchers lumped into the genus Kenyapithecus for more than three decades. Following the discovery of this advanced grade of ape at the 14-millionyear-old site of Fort Ternan, Kenya (Leakey 1962), Louis Leakey's Kenyapithecus became a catchall for large-bodied Middle Miocene apes found throughout that country. This was quite reasonable considering the scarcity and fragmentary nature of most specimens, but the eventual discovery of two partial skeletons from sites at Nachola and Kipsaramon caused most workers to identify three distinct genera: Kenyapithecus from Fort Ternan, Nacholapithecus from Nachola (Ishida et al. 1999), and Equatorius from Kipsaramon and Maboko (Ward et al. 1999; Harrison 1992; but see Kelley et al. 2000; Benefit and McCrossin 2000).

Specimens attributed to Equatorius and Nacholapithecus retain a great number of primitive features, reminiscent of the large-bodied STEMs, while displaying a few features that are more advanced relative to Proconsul (Kunimatsu et al. 2004; Ward et al. 1999). In this restricted taxonomy,
Kenyapithecus is somewhat younger and differs not only from the more primitive STEMs but specifically in ways that link it to more modern fossil and living apes (Fig. 3). This is particularly true in the way the cheekbones connect to the maxilla high above the tooth row, in the configuration of the maxillary sinus, and in the shape of the canine teeth (Andrews and Martin 1987; Begun 1994; Harrison 1992; Ward et al. 1999). Only a single postcranial bone is attributed to Kenyapithecus from Fort Ternan, Kenya, and this humerus more closely resembles younger fossil apes and some great apes in the morphology of its elbow region (McCrossin and Benefit 1994; Ward et al. 1999).

By the late Middle Miocene, the African record of fossil apes becomes very sparse; a few fragmentary specimens span the intervening time prior to the appearance of the earliest fossil humans around seven million years ago. These few, however, seem to represent late-surviving members of the STEM primates (Begun 2007; Hill et al. 2002; Kunimatsu et al. 2007; Olejniczak et al. 2009) and perhaps early examples of the lineage of African apes and humans (see below). Meanwhile, it is Europe and Asia that record the subsequent chapters of ape evolution through the Middle and Late Miocene. In fact, the terrestrial connection between Africa and Eurasia that began in the Early Miocene is paralleled in a taxonomic connection between fossil sites in Kenya and Turkey, with a newly named species of Kenyapithecus (Kenyapithecus kizili) from the Turkish site of Paşalar (Kelley et al. 2008).

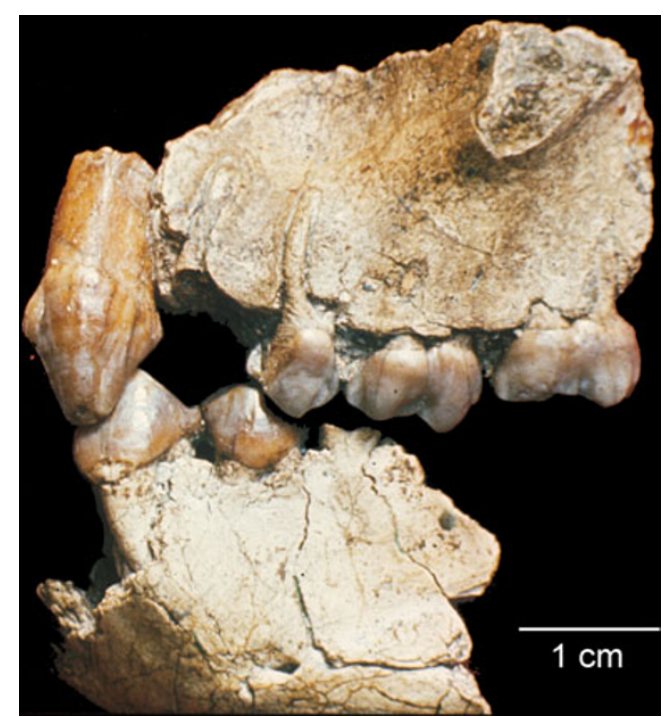

Fig. 3 Composite representation of the upper and lower dentition of Kenyapithecus wickeri (KNM-FT 46a/b and FT 45). The "sectioned" cheekbone in the upper right-hand corner of the figure shows the relatively high placement of this bone relative to the rest of the face, a feature shared with modern apes. Only one postcranial bone can be attributed to Kenyapithecus (in the strictest sense), but partial skeletons of Equatorius and Nacholapithecus are thought by some to be closely related to or even part of this genus. Photo courtesy of Eric Delson 


\section{European Apes}

After apes first appear in Eurasia 16.5 Ma, the record of their tenure there disappears until about $13 \mathrm{Ma}$. Subsequent to that, a diversity of fossil apes evolves over the next seven million years, spanning the broadest reaches of the Eurasian landmass. While some researchers have integrated both European and Asian fossil apes into a broad clade leading ultimately to the orangutans (e.g., Moyà Solà and Köhler 1993; Köhler et al. 2001), the geographic organization adopted here (see Begun 2005) reflects the more widely held opinion that the Asian fossils are specifically related to the orangutan (but see Pilbeam 1997), while European fossil apes are more broadly ancestral to all great apes (Andrews 1992; Andrews and Martin 1991; Harrison 2010; Harrison and Rook 1997), with perhaps one or two grouped more closely with African apes (Begun 2002, 2009; Begun and Kordos 1997; Rose 1997).

The widespread and highly successful ape Dryopithecus is the best ambassador of the European fossil hominoids (Fig. 4). Dryopithecus was formally named from fossils in southern France but now encompasses more than a dozen localities across Europe and perhaps extending even into Georgia (Vekua et al. 2009) and China (Xu and Delson 1988; but see Harrison 2005; Begun 2007). Dryopithecus exhibits a complete departure from the quadrupedal postures associated with earlier apes, instead displaying elongated arms and the large, powerful hands and fingers of a true suspensory ape. Facial features in the snout that were presaged in the Middle Miocene fossils like Kenyapithecus are displayed and further developed in Dryopithecus. Adding to that, the upper face of Dryopithecus, particularly the area above and between the orbits, begins to resemble the brow ridges that characterize living African apes (Begun 1994, 2002, 2007; Kordos and Begun 2001). In Dryopithecus,

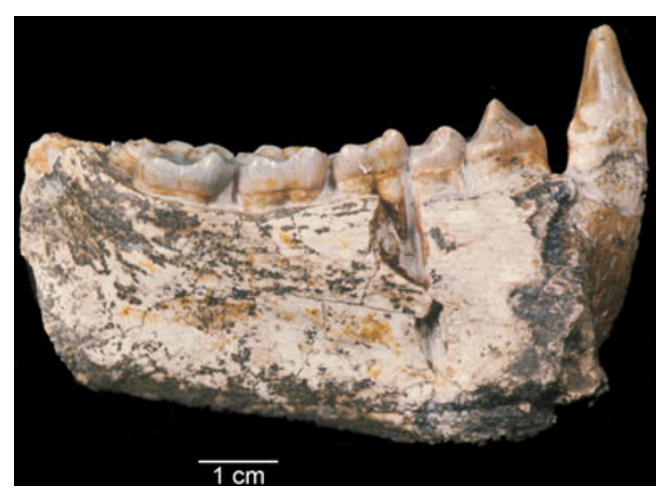

Fig. 4 Mandible of Dryopithecus fontani from France. One of the first fossil apes ever described, this genus was known mostly from isolated dental remains until work in the 1990s uncovered partial skeletons of Dryopithecus in Spain and Hungary. These specimens confirmed that this ape shared advanced suspensory adaptations with modern great apes. Photo courtesy of Eric Delson then, and other European apes (e.g., Begun and Ward 2005), we see that many different parts of the skeleton take on a more modern aspect (but see Harrison 2005; Pilbeam 1997), similar to the living great apes or even African apes.

One of the most fascinating European apes is named Oreopithecus and was found in seven-million-year-old deposits in Italy and Sardinia. Like Sardinia today, much of Italy was an island during that time, and in that isolation, Oreopithecus evolved some interesting characteristics. In the history of paleoanthropology, this ape has occupied a wide variety of phylogenetic positions, including being associated with Old World monkeys (Szalay and Delson 1979) or the primitive African STEM Nyanzapithecus (Harrison 1986; von Koenigswald 1969). Today it is recognized as a true ape (e.g., Harrison and Rook 1997) and is particularly relevant here because of its unique skeletal features. Several authors (Köhler and Moyà Solà 1997; Rook et al. 1999) have interpreted the foot and pelvis of Oreopithecus as indicative of bipedal postures, arguing that relaxed predation pressures on an island might have promoted increased terrestriality. In particular, they argue that the foot of Oreopithecus was built to support an upright stance during prolonged bipedal feeding and perhaps bipedal shuffling between food resources (Köhler and Moyà Solà 1997). Both pedal and pelvic evidence for bipedalism have been criticized, and there is strong evidence for suspensory adaptations in this ape (Begun 2007; Wunderlich et al. 1999). Nevertheless, the scenario suggested for the bipedal evolution of Oreoptihecus is similar to some (e.g., Jolly 1970) proposed for the origins of human bipedal postures.

\section{Asian Apes}

The modern geographic distinction between Europe and Asia might very well have delineated major lineages of apes in the Miocene (Begun 2005; but see, e.g., Köhler et al. 2001). Excepting the scanty "dryopith"-like remains in Georgia and China, this phylogeographic separation makes intuitive sense given the narrow terrestrial connections between the two continents that lie within latitudes inhabitable by apes. Indeed, these zones of faunal interchange would have been complicated and disrupted during the Miocene by shifting arrangements of landmasses and pre-Mediterranean water bodies as Eurasia gradually accommodated the tectonic apposition of the African continent (see, e.g., Rögl 1998; Harzhauser and Piller 2007).

There are several genera of Asian apes in the Middle and Late Miocene, and a broad consensus places most of these on the pongine lineage, related to the modern orangutan (but see Pilbeam 1997; McCrossin and Benefit 1997; 
Pilbeam and Young 2004). One notable exception is the recently named Yuanmoupithecus (Pan 2006), which represents the only known Miocene antecedent to the modern lesser ape Hylobates (Harrison 2010). The best known of the Asian apes is Sivapithecus, found primarily in India and Pakistan between $\sim 12$ and 7 million years ago. Discovery of a partial skull of Sivapithecus confirmed a number of shared derived features with the orangutan genus Pongo (Fig. 5): narrow, rib-like brow rims; tall, oval orbits; eyes placed very close together; and a snout and cheekbones that angle upward relative to the plane of the eyes (Ward 1997b; Ward and Brown 1986; Ward and Pilbeam 1983). The few known postcranial specimens attributed to Sivapithecus, however, suggest that its positional repertoire was vastly different from that of the slow-climbing orangutan. Intriguing similarities to Proconsul and even some Old World monkeys - above-branch quadrupeds in both cases - have led some researchers (e.g., McCrossin and Benefit 1997) to conclude that Sivapithecus is not closely related to the orangutan but instead a more primitive, basal hominoid. However, the odd combination of monkey-like, ape-like, and unique skeletal features in the postcranium of Sivapithecus likely reflects a novel positional repertoire without undermining the many characteristics that link this Miocene ape to the modern orangutan (Begun 2007).

It is impossible to describe ape evolution in Asia without mentioning the aptly named Gigantopithecus. Known from one species in the Miocene Siwalik sites of India and Pakistan and a second species that survived to less than one million years ago in Southeast Asia (Rink et al. 2008), this taxon far surpassed the body size of even the largest male gorillas (Johnson 1979). Though only known from isolated mandibles and teeth, this curious ape is relevant here because of an interesting similarity shared with the human lineage: dramatically reduced canines in males and females and the corresponding loss of the canine-premolar honing complex (e.g., Pilbeam 1970; Frayer 1973; Wang 2009). In species that have large canines, which include most fossil and living apes, this complex provides for the upper canines to be continually sharpened by wearing ("honing") against the tooth immediately behind the lower canine: the $\mathrm{P}_{3}$. Apes that have reduced their canine size, like humans, may lose the canine-premolar honing complex. Thus, based partly on the reduced size and dimorphism of its canines, some early researchers suggested that Gigantopithecus might be intermediate between apes and humans (Weidenreich 1946) or even directly ancestral to the human lineage (Eckhardt 1972, 1973, 1975; Frayer 1973; Robinson and Steudel 1973). However, it is now widely accepted that this terminal gargantuan lineage represents a branch in the evolutionary history of pongines.

\section{Ancestral African Apes}

With the exception of the human lineage, there are almost no fossils that can be linked to modern African apes. Recent discovery of isolated chimpanzee teeth, dating to around 500,000 years ago (McBrearty and Jablonski 2005), are the first good examples linked to an African ape genus. Beyond these few specimens, the evolutionary history of Gorilla and Pan is completely unknown. The preponderance of Eurasian apes during the Late Miocene has prompted many workers (e.g., Begun et al. 1997; Begun 2005; Stewart and

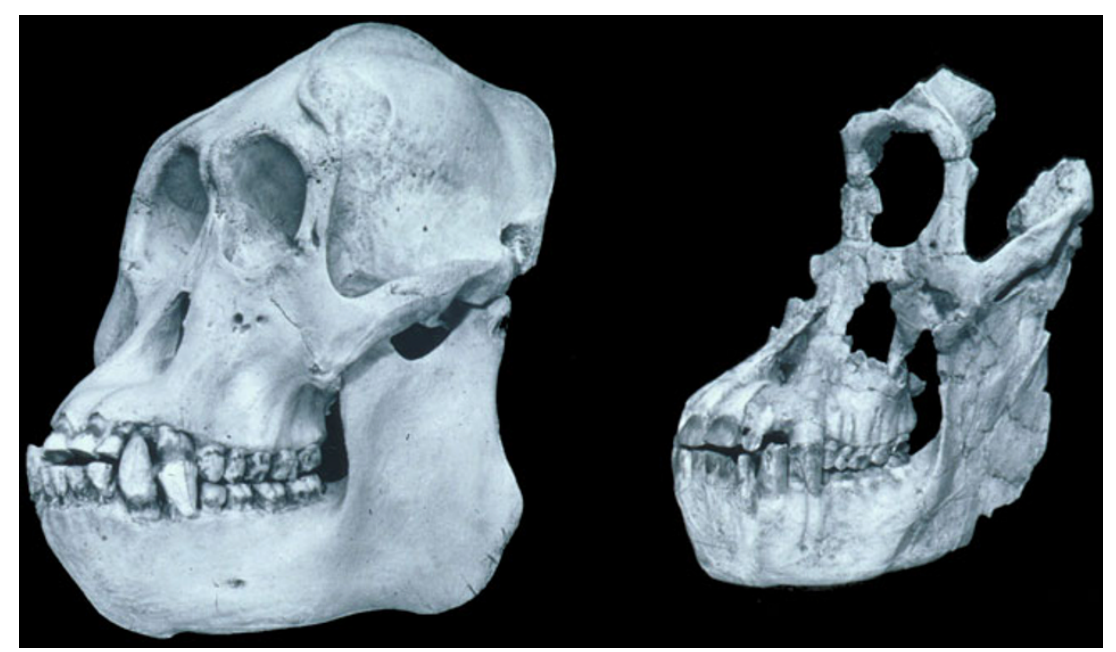

Fig. 5 Comparison of an orangutan (left) and a cast of Sivapithecus indicus (GSP 15000). Discovery of this particular fossil confirmed for most researchers that Sivapithecus belongs in the lineage that gave rise to orangutans. Some of their shared features include: tall, oval-shaped eye sockets; a very narrow region between the eyes; a small, discontinuous brow "ridge" or "rib"; and an upwardly directed palate. The few limb bones that are known from Sivapithecus are very different from the modern orangutan, however, which has led a few researchers to conclude that this fossil is actually a primitive ape rather than an ancestral orangutan. Photo courtesy of Eric Delson 
Disotell 1998) to suggest that the African ape lineage arose in the northern continents, likely in Europe, before migrating into Africa. Begun (e.g., Begun 1994, 2002, 2005, 2007, 2009; Begun et al. 1997; Begun and Kordos 1997) includes Dryopithecus among these ancestral hominines (the lineage of African apes and humans), but the Greek taxon Ouranopithecus is seen by many researchers as the best candidate for this role (Benefit and McCrossin 1995; Andrews 1992; Andrews 1990; Dean and Delson 1992; Andrews et al. 1996; McNulty 2005; but see Köhler et al. 2001).

Ouranopithecus was a large-bodied hominoid, about the size of a female gorilla, with a robust jaw and large dentition for powerful chewing (Begun and Kordos 1997; de Bonis and Koufos 1994; Kelley 2001; Fig. 6). It had a thick, distinct brow ridge that projected in the midline like a gorilla and a downward-directed face similar to the African apes (de Bonis and Koufos 1994, 1997, 2001; Dean and Delson 1992; McNulty 2005). One of the intriguing features of Ouranopithecus is a reduction in canine size and loss of the canine-premolar honing complex, which led some authors (de Bonis and Koufos 1994, 1997, 2001) to conclude that this ape was directly ancestral to the human lineage. This view is not shared by most researchers, and Kelley (2001) has even argued that canine size in Ouranopithecus may not be reduced at all compared to

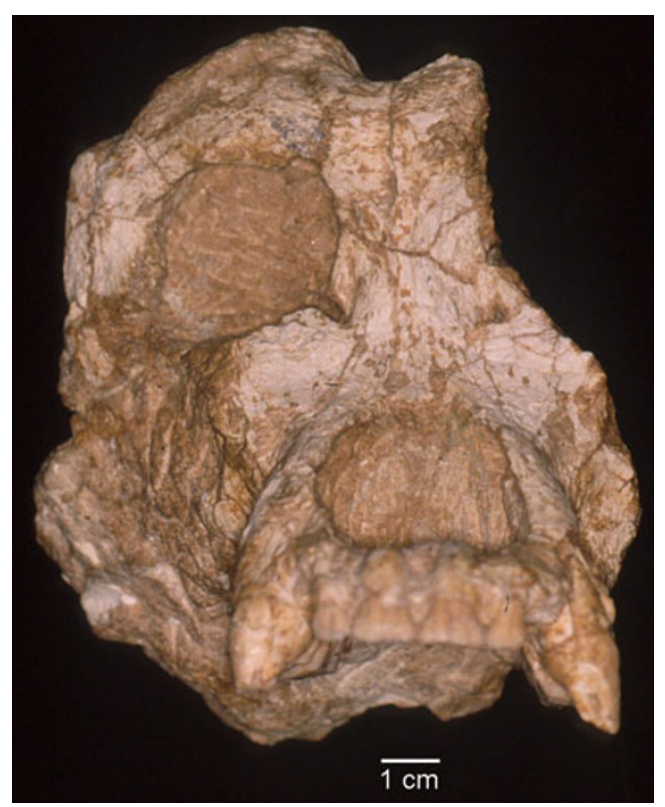

Fig. 6 Cranium of Ouranopithecus macedoniensis. The size of a female gorilla, this genus represents a possible ancestor to the gorillachimpanzee-human lineage. A popular hypothesis suggests that fossil apes in Eurasia eventually gave rise to African apes after some group (perhaps Ouranopithecus) migrated back to the Southern continent. This hypothesis is difficult to test, however, because of a poor fossil record from this time period in Africa. Photo courtesy of Eric Delson living great apes despite its small size relative to canines in earlier hominoid taxa (de Bonis and Koufos 1994).

One difficulty in assessing the validity of a European origin of African ape lineage is that the fossil record in the Late Miocene of Africa is so poor. For many years, a single fragmentary maxillary fossil named Samburupithecus was the best evidence of Late Miocene fossil apes in East Africa (Hill and Ward 1988; Ishida and Pickford 1997), though it is now recognized as a more primitive ape-perhaps even a late-surviving STEM lineage (Begun 2002, 2007)-and probably unrelated to the African apes. In 2007, however, two new fossil apes were announced from Late Miocene sites in Ethiopia and Kenya. Nakalipithecus from Kenya is nearly ten million years old and thought by its discoverers to represent the ancestral features of the African apes (Kunimatsu et al. 2007). Chororapithecus from Ethiopia is slightly older (10.5-10.0 million years ago) and has a size and morphology suggestive of modern gorillas (Suwa et al. 2007). Both of these recent finds are currently known from only a few specimens, and consensus on their evolutionary relationships awaits a broader review of the evidence by the scientific community. Nevertheless, a more complete Late Miocene record from Africa will provide a better test of the relationships between the living African apes and European fossil taxa. Ultimately, until we have a thorough understanding of the evolutionary history of gorillas, chimpanzees, and their hominine ancestors, we cannot do more than speculate about the features that characterized the humanchimpanzee common ancestor and therefore the origin of the human lineage.

\section{Origin of the Human Branch}

Given this complex and tangled prehistory of apes (and tricksters), what can be said about the context of human origins? Many of the traits that we associate with humanslarge brains, complex tool use, language, consciousnessalmost certainly occurred long after our lineage parted ways with the ancestors of chimpanzees. If we retrace our steps on the hominin branch back toward their origin, two key features seem important: reduced canines (with the corresponding loss of the canine-premolar honing complex) and bipedalism. It is these traits that seem to distinguish even the oldest hominins from their simian cousins, and evidence of these features is repeatedly cited to demonstrate the "human-ness" of new fossil discoveries (Brunet et al. 2002; Leakey et al. 1995; Senut et al. 2001; White et al. 1994, 2009).

As has been shown here, however, reduction in canine size and the loss of the honing complex has happened several times in the fossil record of apes. Ouranopithecus, Gigantopithecus, and Oreopithecus all display some degree of canine 
reduction. This can also be seen in the modern pygmy chimpanzee, Pan paniscus (Kelley 2001). Complicating the matter is that most species of female apes have canines that are much smaller than their male counterparts (curiously, the monomorphic gibbons have "masculinized" canines in both males and females). Thus, identifying a fossil human from canine size requires that one clearly distinguish between male and female specimens on some criterion other than canine size and that one rule out alternative, convergent canine reductions such as those seen in recent fossil apes. Extracting that amount of information from the miserly fossil record can be difficult.

Bipedalism, then, and the many features that correspond to it, seems the best diagnostic measure of fossil humans. The bipedal postures of Oreopithecus are the best example of this behavior occurring convergently among apes (Köhler and Moyà Solà 1997; Rook et al. 1999), but this evidence is debatable (Begun 2007; Wunderlich et al. 1999). Bipedal postures also occur in the living great apes as they climb and clamber through the trees and in gibbons, which walk bipedally when they descend to the ground (e.g., Weidenreich 1946). These behaviors, even if they are relevant to the origin of bipedalism (Harcourt-Smith and Aiello 2004; Thorpe et al. 2007), do not permeate the skeleton in any significant way, however, and therefore do not confuse the identification of obligate bipeds in the fossil record. On the other hand, if occasional bipedalism in an arboreal context was generative in human prehistory (see, e.g., Begun 2005), then the diagnostic utility of bipedal skeletal morphology may diminish as one gets closer to the origin of our lineage. Add to this the complications of identifying bipedalism from cranial features (Biegert 1963) and the likely mosaic nature of bipedal evolution among contemporary fossil human species (Harcourt-Smith and Aiello 2004), and the debates that surround human origins seem not only reasonable but quite expected.

Identifying the earliest humans means, by necessity, that we can differentiate them from ancestral chimpanzees and gorillas. With little or nothing known about the ancestral forms of our closest relatives, we can at best impute their features using the modern species: a top-down approach. This is wrong on logical grounds-gorillas and chimpanzees have evolved over as long a time period as humans have - but is intuitively attractive because it seems obvious that the magnitude of human evolutionary change over this time has been substantially greater. The implications of this fact are easily misunderstood: while chimpanzees may be more similar to our last common ancestor than are modern humans, they still may not be very similar. Using chimpanzees as a model for the ancestral human may be greatly misleading (Senut 2007; White et al. 2009), and this is precisely why a detailed knowledge of ape evolution is so important to human origins research (Andrews and Harrison
2005). In the absence of a robust fossil record of gorillas and chimpanzees, it is only through a complimentary bottom-up approach - using the morphological diversity generated through 20 million years of ape evolution - that we can build reasonable hypotheses about the ancestral form which gave rise to the first fossil humans.

\section{References}

Andrews P. Lining up the ancestors. Nature. 1990;345:664-5.

Andrews P. Evolution and environment in the hominoidea. Nature. 1992;360:641-6.

Andrews P, Harrison T. The last common ancestor of apes and humans. In: Lieberman DE, Smith RJ, Kelley J, editors. Interpreting the past: essays on human, primate, and mammal evolution in honor of David Pilbeam. Boston: Brill Academic; 2005. p. 103-21.

Andrews P, Martin LB. Cladistic relationships of extant and fossil hominoids. J Hum Evol. 1987;16:101-18.

Andrews P, Martin L. Hominoid dietary evolution. Phil Trans R Soc Lond B. 1991;334:199-209.

Andrews P, Harrison T, Delson E, Bernor RL, Martin L. Distribution and biochronology of European and Southwest Asian Miocene catarrhines. In: Bernor RL, Fahlbusch V, Mittmann H-W, editors. The evolution of Western Eurasian Neogene mammal faunas. New York: Columbia University Press; 1996. p. 168-295.

Begun DR. Relations among the great apes and humans: new interpretations based on the fossil great ape Dryopithecus. Yrbk Phys Anthropol. 1994;37:11-63.

Begun DR. European hominoids. In: Hartwig W, editor. The primate fossil record. Cambridge: Cambridge University Press; 2002. p. 339-68.

Begun DR. Sivapithecus is East and Dryopithecus is West, and never the twain shall meet. Anthropol Sci. 2005;113:53-64.

Begun DR. Fossil record of Miocene hominoids. In: Henke W, Rothe $\mathrm{H}$, Tattersall I, editors. Handbook of palaeoanthropology, volume 2: primate evolution and human origins. Berlin: Springer; 2007. p. $921-77$.

Begun DR. Dryopithecins, Darwin, de Bonis, and the European origin of the African apes and human clade. Geodiversitas. 2009;31:789-816.

Begun DR, Kordos L. Phyletic affinities and functional convergence in Dryopithecus and other Miocene and living hominids. In: Begun DR, Ward CV, Rose MD, editors. Function, phylogeny and fossils: Miocene hominoid evolution and adaptations. New York: Plenum; 1997. p. 291-316.

Begun DR, Ward CV. Comment on "Pierolapithecus catalaunicus, a new Middle Miocene great ape from Spain. Science. 2005;308:203c.

Begun DR, Ward CV, Rose MD. Events in hominoid evolution. In: Begun DR, Ward CV, Rose MD, editors. Function, phylogeny and fossils: Miocene hominoid evolution and adaptations. New York: Plenum; 1997. p. 389-415.

Benefit BR, McCrossin ML. Miocene hominoids and hominid origins. Ann Rev Anthropol. 1995;24:237-56.

Benefit BR, McCrossin ML. Middle Miocene hominoid origins. Science. 2000;287:2375a.

Biegert J. The evaluation of characters of the skull, hands and feet for primate taxonomy. In: Washburn SL, editor. Classification and human evolution. Chicago: Aldine; 1963. p. 116-45.

Bishop WW, Miller JA, Fitch FJ. New potassium-argon age determinations relevant to the Miocene fossil mammal sequence in East Africa. Am J Sci. 1969;267:669-99. 
Boschetto HB, Brown FH, McDougall I. Stratigraphy of the Lothidok Range, Northern Kenya, and K/Ar Ages of its Miocene primates. J Hum Evol. 1992;22:47-71.

Brunet M, Guy F, Pilbeam D, Taisso Mackaye H, Likius A, Ahounta D, et al. A new hominid from the Upper Miocene of Chad, central Africa. Nature. 2002;418:145-51.

Caccone A, Powell JR. DNA divergence among hominoids. Evolution. 1989;43:925-42.

de Bonis L, Koufos GD. Our ancestors' ancestor: Ouranopithecus is a Greek link in human ancestry. Evol Anthropol. 1994;3:75-83.

de Bonis L, Koufos G. The phylogenetic and functional implications of Ouranopithecus macedoniensis. In: Begun DR, Ward CV, Rose MD, editors. Function, phylogeny and fossils: Miocene hominoid evolution and adaptations. New York: Plenum; 1997. p. 317-26.

de Bonis L, Koufos GD. Phylogenetic relationships of Ouranopithecus macedoniensis (Mammalia, Primates, Hominoidea, Hominidae) of the late Miocene deposits of Central Macedonia. In: de Bonis L, Koufos GD, Andrews P, editors. Hominoid evolution and climatic change in Europe, volume 2: phylogeny of the Neogene hominoid primates of Eurasia, vol. 2. Cambridge: Cambridge University Press; 2001. p. 254-68.

Dean D, Delson E. Second gorilla or third chimp? Nature. 1992;359:676-7.

Eckhardt RB. Population genetics and human origins. Sci Am. 1972;226:94-103

Eckhardt RB. Gigantopithecus as a hominid ancestor. Anthropol Anz. 1973;34:1-8

Eckhardt RB. Gigantopithecus as a hominid. In: Tuttle RL, editor. Paleoanthropology, morphology and paleoecology. The Hague: Mouton; 1975. p. 105-27.

Frayer D. Gigantopithecus and its relationship to Australopithecus. Am J Phys Anthropol. 1973;39:413-26.

Gebo DL, MacLatchy L, Kityo R, Deino A, Kingston J, Pilbeam D. A hominoid genus from the Early Miocene of Uganda. Science. 1997;276:401-4.

Goodman M, Tagle DA, Fitch DH, Bailey W, Czelusniak J, Koop BF, et al. Primate evolution at the DNA level and a classification of hominoids. J Mol Evol. 1990;30:260-6.

Harcourt-Smith WEH, Aiello LC. Fossils, feet and the evolution of human bipedal locomotion. J Anat. 2004;204:403-16.

Harrison T. A reassessment of the phylogenetic relationship of Oreopoithecus bambolii Gervais. J Hum Evol. 1986;15:541-83.

Harrison T. The phylogenetic relationships of the early catarrhine primates: a review of the current evidence. J Hum Evol. 1987;16:41-80.

Harrison T. A taxonomic revision of the small catarrhine primates from the Early Miocene of East Africa. Folia Primatol. 1988;50:59-108.

Harrison T. A reassessment of the taxonomic and phylogenetic affinities of the fossil catarrhines from fort Ternan, Kenya. Primates. 1992;33:501-22.

Harrison T. Cladistic concepts and the species problem in hominoid evolution. In: Martin L, Kimbel W, editors. Species, species concepts, and primate evolution. New York: Plenum; 1993. p. 345-71.

Harrison T. Late Oligocene to Middle Miocene catarrhines from AfroArabia. In: Hartwig W, editor. The primate fossil record. Cambridge: Cambridge University Press; 2002. p. 311-38.

Harrison T. The zoogeographic and phylogenetic relationships of early catarrhine primates in Asia. Anthropol Sci. 2005;113:43-51.

Harrison T. Apes among the tangled branches of human origins. Nature. 2010;327:532-4.

Harrison T, Rook L. Enigmatic anthropoid or misunderstood ape: the phylogenetic status of Oreopithecus bambolii reconsidered. In: Begun DR, Ward CV, Rose MD, editors. Function, phylogeny and fossils: Miocene hominoid evolution and adaptations. New York: Plenum; 1997. p. 327-62.

Harzhauser M, Piller WE. Benchmark data of a changing seapalaeogeography, palaeobiogeography and events in the Central Paratethys during the Miocene. Palaeogeogr Palaeoclimatol Palaeoecol. 2007;253:8-31.

Heizmann E, Begun DR. The oldest European hominoid. J Hum Evol. $2001 ; 41: 465-81$.

Hill A, Ward S. Origin of the hominidae: the record of African large hominoid evolution between 14 my and 4 my. Yrbk Phys Anthropol. 1988;32:48-83.

Hill A, Leakey M, Kingston JD, Ward S. New cercopithecoids and a hominoid from 12.5 Ma in the Tugen Hills Succession, Kenya. J Hum Evol. 2002;42:75-93.

Hunt KD, Cant JGH, Gebo DL, Rose MD, Walker SE, Youlatos D. Standardized descriptions of primate locomotor and postural modes. Primates. 1996;37:363-87.

Ishida H, Pickford M. A new Late Miocene hominoid from Kenya: Samburupithecus koptalami gen. et Sp. Nov. C R Acad Sci Ser D. 1997;325:823-9.

Ishida H, Kunimatsu Y, Nakatsukasa M, Nakano Y. New hominoid genus from the Middle Miocene of Nachola, Kenya. Anthropol Sci. 1999;107:189-91.

Johnson Jr AE. Skeletal estimates of Gigantopithecus based on a gorilla analogy. J Hum Evol. 1979;8:585-7.

Jolly CJ. The seed-eaters: a new model of hominid differentiation based on a baboon analogy. Man. 1970;5:5-26.

Kelley J. Paleobiological and phylogenetic significance of life history in Miocene hominoids. In: Begun DR, Ward CV, Rose MD, editors. Function, phylogeny and fossils: Miocene hominoid evolution and adaptations. New York: Plenum; 1997. p. 173-208.

Kelley J. Hominoid evolution and climate change in Europe: phylogeny of the Neogene hominoid primates of Eurasia. In: de Bonis L, Koufos GD, Andrews P, editors. Hominoid Evolution and Climatic Change in Europe, Phylogeny of the Neogene Hominoid Primates of Eurasia, vol. 2. Cambridge: Cambridge University Press; 2001. p. 269-71.

Kelley J, Ward S, Brown B, Hill A, Downs W. Middle Miocene hominoid ancestors. Science. 2000;287:2375A

Kelley J, Andrews P, Alpagut B. A new hominoid species from the Middle Miocene site of Paşalar, Turkey. J Hum Evol. 2008;54:455-79.

Köhler M, Moyà Solà S. Ape-like or hominid-like? The positional behavior of Oreopithecus bambolii reconsidered. Proc Natl Acad Sci USA. 1997;94:11747-50.

Köhler M, Moyà Solà S, Alba DM. Eurasian hominoid evolution in the light of recent Dryopithecus findings. In: de Bonis L, Koufos GD, Andrews P, editors. Hominoid evolution and climatic change in Europe, volume 2: phylogeny of the Neogene hominoid primates of Eurasia, vol. 2. Cambridge: Cambridge University Press; 2001. p. 193-212.

Kordos L, Begun DR. A new cranium of Dryopithecus from Rudabánya, Hungary. J Hum Evol. 2001;41:689-700.

Kunimatsu Y, Ishida H, Nakatsukasa M, Nakano Y, Sawada Y. Maxillae and associated gnathodental specimens of Nacholapithecus kerioi, a large-bodied hominoid from Nachola, Northern Kenya. J Hum Evol. 2004:46:365-400

Kunimatsu Y, Nakatsukasa M, Sawada Y, Sakai T, Hyodo M, Hyodo $\mathrm{H}$, et al. A new Late Miocene great ape from Kenya and its implications for the origins of African great apes and humans. Proc Natl Acad Sci USA. 2007;104:19220-5.

Leakey LSB. A new lower pliocene fossil primate from Kenya. Ann Mag Nat Hist. 1962;13:689-96.

Leakey MG, Feibel CS, McDougall I, Walker AC. New four-millionyear-old species from Kanapoi and Allia Bay, Kenya. Nature. 1995;376:565-71. 
MacLatchy L. The oldest ape. Evol Anthropol. 2004;13:90-103.

MacLatchy L, Gebo D, Kityo R, Pilbeam D. Postcranial functional morphology of Morotopithecus bishopi, with implications for the evolution of modern ape locomotion. J Hum Evol. 2000;38:15983.

MacLatchy L, Deino A, Kingston J. An updated chronology for the Early Miocene of NE Uganda. J Vertebr Paleontol Abstr Pap. 2006;26(3):93A.

McBrearty S, Jablonski NG. First fossil chimpanzee. Nature. 2005;437:105-8.

McCrossin ML, Benefit BR. Maboko Island and the evolutionary history of the Old World monkeys and apes. In: Corruccini RS, Ciochon RL, editors. Integrative paths to the past. Upper Saddle River: Prentice Hall; 1994. p. 95-122.

McCrossin ML, Benefit BR. On the relationships and adaptations of Kenyapithecus, a large-bodied hominoid from the Middle Miocene of Eastern Africa. In: Begun DR, Ward CV, Rose MD, editors. Function, phylogeny and fossils: Miocene hominoid evolution and adaptations. New York: Plenum; 1997. p. 241-67.

McNulty KP. Geometric morphometric analyses of extant and fossil hominoid craniofacial morphology. Unpublished $\mathrm{PhD}$ thesis, City University of New York;2003.

McNulty KP. A geometric morphometric assessment of the hominoid supraorbital region: affinities of the Eurasian Miocene hominoids Dryopithecus, Graecopithecus, and Sivapithecus. In: Slice D, editor. Modern morphometrics in physical anthropology. New York: Kluwer; 2005. p. 349-73.

Moyà-Solà $\mathrm{S}$, Köhler M. Recent discoveries of Dryopithecus shed new light on evolution of great apes. Nature. 1993;365:543-5.

Nakatsukasaa M, Ward CV, Walker A, Teaford MF, Kunimatsu Y, Ogihara N. Tail loss in Proconsul heseloni. J Hum Evol. 2004;46:777-84.

Olejniczak AJ, Begun DR, Mbua E, Hublin J-J. Phyletic affinities of Samburupithecus kiptalami: an Upper Miocene proconsulid. Am J Phys Anthropol S. 2009;48:202.

Pan Y. Lufengpithecus hudiensis site. In: Qi G, Dong W, editors. State Key Projects of the 9th Five Year Plan - Origin of Early Humans and Environmental Background, Series Monograph II. Beijing: Science Press; 2006. p. 320-2.

Peppe DJ, McNulty KP, Cote SM, Harcourt-Smith WEH, Dunsworth HM, Van Couvering JA. Stratigraphic interpretation of the Kulu Formation (Early Miocene, Rusinga Island, Kenya) and its implications for primate evolution. J Hum Evol. 2009;56:447-61.

Pickford M, Andrews P. The Tinderet Miocene sequence in Kenya. J Hum Evol. 1981;10:1-33.

Pickford M, Kunimatsu Y. Catarrhines from the Middle Miocene (ca. 14.5 Ma) of Kipsaraman, Tugen Hills, Kenya. Anthropol Sci. 2005;113:189-224.

Pilbeam D. Gigantopithecus and the origin of Hominidae. Nature. 1970;225:516-9.

Pilbeam DR. Research on Miocene hominoids and hominid origins: the last three decades. In: Begun DR, Ward CV, Rose MD, editors. Function, phylogeny and fossils: Miocene hominoid evolution and adaptations. New York: Plenum; 1997. p. 13-28.

Pilbeam DR, Young N. Hominoid evolution: synthesizing disparate data. C R Palevol. 2004;3:305-21.

Raaum RL, Sterner KN, Noviello CM, Stewart C-B, Disotell TR. Catarrhine primate divergence dates estimated from complete mitochondrial genomes: concordance with fossil and nuclear DNA evidence. J Hum Evol. 2005;48:237-57.

Rae TC. The early evolution of the hominoid face. In: Begun DR, Ward CV, Rose MD, editors. Function, phylogeny and fossils: Miocene hominoid evolution and adaptations. New York: Plenum; 1997. p. 59-77.

Rae TC. Mosaic evolution in the origin of the Hominoidea. Folia Primatol. 1999;70:125-35.
Rae TC. Miocene hominoid craniofacial morphology and the emergence of great apes. Ann Anat. 2004;186:417-22.

Rink WJ, Wei W, Bekken D, Jones HL. Geochronology of Ailuropoda-Stegodon fauna and Gigantopithecus in Guangxi Province, Southern China. Quat Res. 2008;69:377-87.

Robinson JT, Steudel K. Multivariate discriminant analyses of dental data bearing on early hominid affinities. J Hum Evol. 1973;2:509-28.

Rögl F. Palaeogeographic considerations for Mediterranean and Paratethys seaways (Oligocene to Miocene). Ann Naturhist Mus Wien. 1998;99:279-310.

Rook L, Bondioli L, Köhler M, Moyà Solà S, Macchiarelli R. Oreopithecus was a bipedal ape after all: evidence from the iliac cancellous architecture. Proc Natl Acad Sci USA. 1999;96:8795-9.

Rose MD. Miocene hominoid postcranial morphology: monkey-like, ape-like, neither, or both? In: Ciochon RL, Corrucci RS, editors. New interpretations of ape and human ancestry. New York: Plenum; 1983. p. 405-17.

Rose MD. Another look at the anthropoid elbow. J Hum Evol. 1988; 17:193-224.

Rose MD. Kinematics of the trapezium-1st metacarpal joint in extant anthropoids and Miocene hominoids. J Hum Evol. 1992;22:255-6.

Rose MD. Functional anatomy of the elbow and forearm in primates. In: Gebo DL, editor. Postcranial adaptation in nonhuman primates. DeKalb: Northern Illinois University Press; 1993. p. 70-95.

Rose MD. Quadrupedalism in some miocene catarrhines. J Hum Evol. 1994;26:387-411.

Rose MD. Functional and phylogenetic features of the forelimb in Miocene hominoids. In: Begun DR, Ward CV, Rose MD, editors. Function, phylogeny and fossils: Miocene hominoid evolution and adaptations. New York: Plenum; 1997. p. 79-100.

Ruvolo M. Molecular phylogeny of the hominoids: inferences from multiple independent DNA sequence data sets. Mol Biol Evol. 1997;14:248-65.

Ruvolo M, Pan D, Zehr S, Goldberg T, Disotell TR, von Dornum M. Gene trees and hominoid phylogeny. Proc Natl Acad Sci USA. 1994;91:8900-4.

Sanders WJ, Bodenbender BE. Morphometric analysis of lumbar vertebra UMP 67-28: implications for spinal function and phylogeny of the Miocene Moroto hominoid. J Hum Evol. 1994;26:203-37.

Senut B. The earliest putative hominids. In: Henke W, Rothe H, Tattersall I, editors. Handbook of palaeoanthropology, volume 2: primate evolution and human origins. Berlin: Springer; 2007. p. 1519-38.

Senut B, Pickford M, Gommery D, Mein P, Kiptalam C, Coppens Y. First hominid from the Miocene (Lukeino Formation, Kenya). C R Acad Sci Paris. 2001;332:137-44.

Simpson JA, Weiner, ESC editors. Oxford English Dictionary, Second Edition. Oxford: Clarendon;1989.

Stewart C-B, Disotell TR. Primate evolution: in and out of Africa. Curr Biol. 1998;8:582-8.

Suwa G, Kono RT, Katoh S, Asfaw B, Beyene Y. A new species of great ape from the Late Miocene Epoch in Ethiopia. Nature. 2007;448:921-4.

Szalay FS, Delson E. Evolutionary history of the primates. New York: Academic; 1979.

Thorpe SKS, Holder RL, Crompton RH. Origin of human bipedalism as an adaptation for locomotion on flexible branches. Science. 2007;316:1328-31.

Vekua A, Lordkipanidze D, Bukhsianidze M, Vanishvili N, Chagelishvili R. Importance of Diliska vertebrate fauna for the biostratigraphy of South Caucasus. Bull Georg Natl Acad Sci. 2009;3:130-5.

von Koenigswald GHR. Miocene Cercopithecoidea and Oreopithecoidea from the Miocene of East Africa. Fossil Vertebr Afr. $1969 ; 1: 39-52$ 
von Linnaeus C. Systema Naturae, Tenth Edition. New York: Weldon \& Wesley;1759. p. 1384.

Walker AC, Rose M. Some hominoid vertebrae from the Miocene of Uganda. Nature. 1968;217:980-1.

Wang W. New discoveries of Gigantopithecus blacki teeth from Chuifeng cave in the Bubing Basin, Guangxi, South China. J Hum Evol. 2009;57:229-40.

Ward CV. Functional anatomy and phyletic implications of the hominoid trunk and hindlimb. In: Begun DR, Ward CV, Rose MD, editors. Function, phylogeny and fossils: Miocene hominoid evolution and adaptations. New York: Plenum; 1997a. p. 101-30.

Ward S. The taxonomy and phylogenetic relationships of Sivapithecus revisited. In: Begun DR, Ward CV, Rose MD, editors. Function, phylogeny and fossils: Miocene hominoid evolution and adaptations. New York: Plenum; 1997b. p. 269-90.

Ward S, Brown B. The facial skeleton of Sivapithecus indicus. In: Swindler DR, Erwin J, editors. Comparative primate biology. New York: Alan R. Liss; 1986. p. 413-52.

Ward SC, Duren DL. Middle and Late Miocene African hominoids. In: Hartwig W, editor. The Primate Fossil Record. Cambridge: Cambridge University Press; 2002. p. 385-97.
Ward SC, Kimbel WH. Subnasal alveolar morphology and the systemic position of Sivapithecus. Am J Phys Anthropol. 1983;61:157-71.

Ward SC, Pilbeam DR. Maxillofacial morphology of Miocene hominoids from Africa and Indo-Pakistan. In: Corruccini RL, Ciochon RS, editors. New interpretations of ape and human ancestry. New York: Plenum; 1983. p. 211-38.

Ward CV, Walker A, Teaford MF. Proconsul did not have a tail. J Hum Evol. 1991;21:215-20.

Ward S, Brown B, Hill A, Kelley J, Downs W. Equatorius: a new hominoid genus from the Middle Miocene of Kenya. Science. 1999;285:1382-6.

Weidenreich F. Apes, giants and man. Chicago: University of Chicago Press; 1946.

White TD, Suwa G, Asfaw B. Australopithecus ramidus, a new species of early hominid from Aramis, Ethiopia. Nature. 1994;371:306-12.

White TD, Asfaw B, Beyene Y, Haile-Selassie Y, Lovejoy CO, Suwa $\mathrm{G}$, et al. Ardipithecus ramidus and the paleobiology of early hominids. Science. 2009;326:75-86.

Wunderlich RE, Walker A, Jungers WL. Rethinking the positional repertoire of Oreopithecus. Am J Phys Anthropol. 1999;108:528.

$\mathrm{Xu}$ X, Delson E. A new species of Dryopithecus from Gansu, China. Kexue Tongbao. 1988;33:449-53. 